\title{
Reproductive performance of silver catfish fed sorghum diets supplemented with phytase
}

\author{
Mariana Lins Rodrigues ${ }^{(1)}$, Milena Souza dos Santos Sanchez ${ }^{(1)}$, Danielle Zanerato Damasceno(2), \\ Fábio Bittencourt ${ }^{(1)}$, Adilson Reidel ${ }^{(3)}$, Nelson Mauricio Lopera Barrero(4) and Altevir Signor ${ }^{(1)}$
}

\begin{abstract}
(1)Universidade Estadual do Oeste do Paraná, Rua da Faculdade, № 645, Caixa Postal 320, Jardim Santa Maria, CEP 85903-000 Toledo, PR, Brazil. E-mail: lins.mariana@hotmail.com, milenasanchezzoo@hotmail.com, fabio.gemaq@gmail.com, altevir.signor@gmail.com (2)Universidade Estadual Paulista Júlio de Mesquita Filho, Centro de Aquicultura, Via de Acesso Prof. Paulo Donato Castellane, s/no, CEP 14884-900 Jaboticabal, SP, Brazil. E-mail: danizanerato@hotmail.com ${ }^{(3)}$ Instituto Federal do Paraná, Campus Foz do Iguaçu, Avenida Araucária, no 780, Vila Residencial A, CEP 85860-000 Foz do Iguaçu, PR, Brazil. E-mail: adilson.reidel@ifpr.edu.br (4)Universidade Estadual de Londrina, Rodovia Celso Garcia, Km 380, Campus Universitário, CEP 86051-980 Londrina, PR, Brazil. E-mail: nmlopera@uel.br
\end{abstract}

Abstract - The objective of this work was to evaluate the reproductive performance of silver catfish (Rhamdia quelen) fed diets containing sorghum, as a replacement for corn, supplemented or not with phytase. The experiment was carried out with 360 fish, with $16.02 \pm 0.58 \mathrm{~g}$ mean initial weight, fed diets in which low-tannin sorghum replaced corn at 0,50 , and $100 \%$, with or without phytase supplementation (1,500 FTU per kilogram of feed). Diets supplemented with phytase or with $100 \%$ sorghum led to a reduction of visceral fat deposition and hepatic mass in males. In females, similar results were observed for diets containing phytase. Females fed sorghum-only diets, supplemented or not with phytase, had bigger oocytes. Males and females at the developing and final stages of gonadal maturation were found in all treatments. The replacement of corn by sorghum affects neither semen quality nor the fertilization rate of gametes. Therefore, complete replacement of corn with low-tannin sorghum in the diet can be performed without compromising the reproductive performance or the somatic indexes of silver catfish.

Index terms: Rhamdia quelen, alternative food, breeding nutrition, histology, quality of gametes.

\section{Desempenho reprodutivo de jundiá alimentado com dietas com sorgo suplementadas com fitase}

\begin{abstract}
Resumo - O objetivo deste trabalho foi avaliar o desempenho reprodutivo de jundiá (Rhamdia quelen) alimentado com dietas contendo sorgo em substituição ao milho, suplementadas ou não com fitase. $\mathrm{O}$ experimento foi realizado com 360 jundiás, com peso médio inicial de 16,02 $\pm 0,58 \mathrm{~g}$, alimentados com dietas compostas por 0,50 e $100 \%$ de sorgo de baixo tanino, em substituição ao milho, com ou sem a suplementação de fitase (1.500 UFA por quilograma da dieta). Dietas com suplementação de fitase ou com $100 \%$ de sorgo reduziram a deposição de gordura visceral e a massa hepática nos machos. Nas fêmeas, o mesmo efeito foi observado quanto às dietas com suplementação de fitase. As fêmeas alimentadas com dietas apenas com sorgo, suplementadas ou não com fitase, apresentaram ovócitos maiores. Foram encontrados machos e fêmeas nas fases finais de desenvolvimento e maturação gonadal, em todos os tratamentos. A substituição do milho pelo sorgo não afeta a qualidade seminal nem a taxa de fertilização dos gametas. Portanto, a substituição completa do milho pelo sorgo de baixo tanino pode ser efetuada sem afetar os parâmetros reprodutivos e os índices somáticos do jundiá.
\end{abstract}

Termos para indexação: Rhamdia quelen, alimento alternativo, nutrição de reprodutores, histologia, qualidade de gametas.

\section{Introduction}

Rhamdia quelen, known as silver catfish, is a native Brazilian species that has been standing out in continental fish farming for having advantageous productive characteristics, such as omnivorous feeding habit, easy adaptation to artificial diets, excellent quality meat, absence of intramuscular spines, easy adaptation to artificial diets, and good acceptance by the consumer market (Carneiro et al., 2003; Fracalossi et al., 2004).

Furthermore, $R$. quelen are able to tolerate low temperatures than most neotropical species, which 
either reduce or cease their growth under these conditions (Fracalossi et al., 2004). Even though $R$. quelen production is good development, the aspects related to this fish reproduction should be studied, in order to generate specific knowledge to allow of a continuous raising with the use of young animals able to be reared in captivity.

It is known that the initial phases of fish development are directly affected by broodstock performance, in which nutrition is one of the limiting factors in successful production of viable larvae, fries, and juveniles. Therefore, the nutritional balance of the diets fed to broodstock can improve oocytes and spermatozoa quality, and increase the gamete production, gonadal development (Reidel et al., 2010; Diemer et al., 2014), and the quality of spawning (Mardini et al., 1981; Izquierdo et al., 2001; Coldebella et al., 2011; Bittencourt et al., 2012).

However, studies on broodstock nutrition are scarce due to the high cost of big facilities, upkeep of adult fish, prolonged feeding, and labor costs (Alvarez-Lajonchère, 2006; Navarro et al., 2006). Feed represents the highest cost for fish farming (Pezzato et al., 2002); therefore, there is a need for the use of alternative ingredients which are available in the market at competitive prices, such as high- and lowtannin sorghum, cassava shavings, triticale, and canola (Rostagno et al., 2011).

Although corn is still the main energy ingredient in commercial feeds, the use of sorghum and other grains has been well established in the farming of monogastric animals. These grains have been used as raw materials at certain times of the year, in order to reduce production costs without compromising the productive performance of the animals (Carvalho et al., 2015). However, the use of sorghum in fish farming is not well documented due to the large number of existing species and their different feeding habits. Nevertheless, this is bound to change, as sorghum corresponds to $80 \%$ of the commercial value of corn (Duarte, 2010) and could reduce the production costs.

Among the commercially available energy ingredients, low-tannin sorghum stands out for having nutritional characteristics similar to corn, with high anti-oxidant effect (Silva et al., 2009), market availability, and affordable price, which could minimize the production costs affected by the price variation of supplies (May et al., 2011).
As with other plant sources, $\mathrm{P}$ is present in sorghum mainly in its phytate form, thus, only $34.6 \%$ of the $0.26 \%$ total $\mathrm{P}$ is available (Valle, 2010). This is due to the phytic acid molecule that makes $\mathrm{P}$ unavailable. Phytic acid forms complexes with essential minerals such as $\mathrm{Ca}, \mathrm{Fe}, \mathrm{Zn}, \mathrm{Cu}, \mathrm{Na}$, and $\mathrm{Mg}$; and interferes with the absorption of amino acids (turning complex amino acids insoluble), of energy (Maenz, 2001), and of starch (Angel et al., 2002).

Therefore, this effect can be reduced by adding the phytase enzyme to the diet. This enzyme acts on the hydrolysis process and on the rupture of feed cellular walls, mainly in the stomach and in the inicial portion of the small intestine, where it breaks up the phytic acid and releases minerals and other nutrients (Ferlin, 2006). Furthermore, it reduces the digesta viscosity in the gastrointestinal tract, increasing total digestibility of the diet and improving nutrient metabolism (Farrel et al., 1993).

The objective of this work was to analyze the reproductive performance of $R$. quelen fed diets containing sorghum, as a replacement for corn, and supplemented or not with phytase.

\section{Materials and Methods}

The experiment took place at Instituto de Pesquisa em Aquicultura Ambiental of Universidade Estadual do Oeste do Paraná (Unioeste), in Toledo, PR, Brazil. The adopted procedures in this study were approved by the ethics committee on animal research (CEUA/ Protocolo n. ${ }^{\circ}$ 63/14). A total of 360 R. quelen juveniles, aged approximately seven months (first sexual maturation), were acclimatized in 24 net cages of $1 \mathrm{~m}^{3}$ usable volume at a density of 15 fish per cage. Fish were randomly distributed into a $2 \times 3$ factorial arrangement, with six treatments and four replicates. Corn (Zea mays L.) was replaced by low-tannin sorghum [Sorghum bicolor (L.) Moench] at three different combinations $(0,50$, and $100 \%)$, supplemented or not with phytase enzyme ( 0 or 1,500 FTU $\mathrm{kg}$ feed). Fish were fed four times a day, for 180 days, with isoproteic (34\% crude protein), isoenergetic (3,565 digestible energy), isofibrous, isocalcitic, isophosphoric and isoaminoacidic diets (Table 1). The ingredients used were ground using a feed hammer mill, weighed, homogenized in a Y-type mixer and, subsequently, extruded using a feed extruder (Exteec, Ribeirão 
Preto, SP, Brazil). Pellets were dried in a forced-air circulation furnace at $55^{\circ} \mathrm{C}$.

After the experimental period, seven males $(23.65 \pm 2.83 \mathrm{~cm}$, and $136.49 \pm 54.94 \mathrm{~g})$ and four females $(23.34 \pm 2.40 \mathrm{~cm}$, and $134.43 \pm 42.35 \mathrm{~g})$ of each treatment were selected for reproduction, based on the visualization of external sexual characteristics: reddened urogenital papillae and distended abdomen in females (Reidel et al., 2010), and semen release after gentle abdominal pressure in males (Diemer et al., 2014). Once selected, the broodstock was transported to the aquaculture laboratory of Unioeste and subjected to induced reproduction with crude carp hypophysis extract. The females received two doses of hormone (0.5 and $5.0 \mathrm{mg} \mathrm{kg}^{-1}$ fish), at 12-hour intervals. The males received a single dose $\left(2.5 \mathrm{mg} \mathrm{kg}^{-1}\right.$ fish $)$ at the same time as females received the second dose. After 240 degree-hours, fish were dried with paper towels and subjected to an abdomen massage in the cephalocaudal direction, for the collection of gametes.

Semen was collected into graduated Falcon tubes for volume quantification, and kept in Styrofoam box with ice at $\pm 12^{\circ} \mathrm{C}$ (adapted from Sanches et al., 2013) until needed for oocyte fertilization.

Sperm concentration was evaluated by diluting $5.0 \mu \mathrm{L}$ semen in $5,000 \mu \mathrm{L}$ buffered formal saline, resulting in 1:1000 concentration (Bombardelli et al., 2006). Counting was carried out using a Neubauer haematimetric chamber (Wirtz \& Steinmann, 2006),

Table 1. Percentage and nutritional composition of corn or sorghum diets supplemented or not with phytase enzyme, and corn-only and sorghum-only diets, fed to Rhamdia quelen broodstock kept in net cages.

\begin{tabular}{|c|c|c|c|c|c|c|}
\hline \multirow[t]{2}{*}{ Ingredient (\%) } & \multicolumn{3}{|c|}{ Phytase, 0 FTU } & \multicolumn{3}{|c|}{ Phytase, $1,500 \mathrm{FTU}^{(1)}$} \\
\hline & Corn & Corn or sorghum & Sorghum & Corn & Corn and sorghum & Sorghum \\
\hline Soybean meal at $42 \%$ & 49.57 & 49.22 & 48.88 & 49.57 & 49.22 & 48.88 \\
\hline Low-tannin sorghum & 0.00 & 17.04 & 34.07 & 0.00 & 17.04 & 34.07 \\
\hline Corn & 30.62 & 15.31 & 0.00 & 30.62 & 15.31 & 0.00 \\
\hline Fish meal at $55 \%$ & 15.00 & 15.00 & 15.00 & 15.00 & 15.00 & 15.00 \\
\hline $\operatorname{Premix}^{(2)}$ & 1.00 & 1.00 & 1.00 & 1.00 & 1.00 & 1.00 \\
\hline L-threonine & 0.37 & 0.38 & 0.38 & 0.37 & 0.38 & 0.38 \\
\hline DL-methionine & 0.34 & 0.34 & 0.35 & 0.34 & 0.34 & 0.35 \\
\hline Choline chloride & 0.10 & 0.10 & 0.10 & 0.10 & 0.10 & 0.10 \\
\hline Vitamin C & 0.10 & 0.10 & 0.10 & 0.10 & 0.10 & 0.10 \\
\hline Antifungal $^{(3)}$ & 0.10 & 0.10 & 0.10 & 0.10 & 0.10 & 0.10 \\
\hline Antioxidant ${ }^{(4)}$ & 0.02 & 0.02 & 0.02 & 0.02 & 0.02 & 0.02 \\
\hline Soybean oil & 2.78 & 1.40 & 0.00 & 2.78 & 1.40 & 0.00 \\
\hline Phytase & 0.00 & 0.00 & 0.00 & 0.30 & 0.30 & 0.30 \\
\hline \multicolumn{7}{|l|}{ Nutrient (\%) } \\
\hline Starch & 25.33 & 26.46 & 27.60 & 25.33 & 26.46 & 27.60 \\
\hline Calcium & 0.83 & 0.83 & 0.83 & 0.83 & 0.83 & 0.83 \\
\hline Digestible energy $\left(\mathrm{kcal} \mathrm{kg}^{-1}\right)^{(6)}$ & $3,565.00$ & $3,565.35$ & $3,565.70$ & $3,565.00$ & $3,565.35$ & $3,565.70$ \\
\hline Available P & 0.48 & 0.48 & 0.49 & 0.48 & 0.48 & 0.49 \\
\hline Fat & 7.99 & 6.57 & 5.15 & 7.99 & 6.57 & 5.15 \\
\hline Total lysine & 2.10 & 2.09 & 2.08 & 2.10 & 2.09 & 2.08 \\
\hline Methionine + Cystine & 1.46 & 1.46 & 1.46 & 1.46 & 1.46 & 1.46 \\
\hline Digestible protein ${ }^{5}$ & 28.29 & 28.39 & 28.48 & 28.29 & 28.39 & 28.48 \\
\hline Crude protein & 34.00 & 34.00 & 34.00 & 34.00 & 34.00 & 34.00 \\
\hline Threonine & 1.73 & 1.73 & 1.73 & 1.73 & 1.73 & 1.73 \\
\hline Tryptophan & 0.42 & 0.42 & 0.42 & 0.42 & 0.42 & 0.42 \\
\hline
\end{tabular}

(1)Phytase level (FTU kg-1) estimated for Rhamdia quelen according to Rocha et al. (2007). ${ }^{(2)}$ Premix composition, and guarantee levels per kilogram of product: vitamin A, 1,750,000 UI; vitamin D3, 375,000 UI; vitamin E, 20,000 UI; vitamin K3, $500 \mathrm{mg}$; vitamin B1, 2.000 mg; vitamin B2, 2,500 mg; vitamin B6, 2,500 mg; vitamin B12, 5,000 mg; folic acid, $625 \mathrm{mg}$; calcium pantothenate, 7,500 mg; vitamin C, $37,500 \mathrm{mg}$; biotin, $50 \mathrm{mg}$; inositol, $12,500 \mathrm{mg}$; niacin, $8,750 \mathrm{mg}$; Co, $50 \mathrm{mg}$; Cu, 1,250 mg; Fe, 15,000 mg; I, $100 \mathrm{mg}$; Mn, 3,750 mg; Se, $75 \mathrm{mg}$; and Zn, 17,500 mg. ${ }^{(3)} \mathrm{Calcium}$ propionate. ${ }^{(4)} \mathrm{BHT}$, butylated hydroxytoluene. ${ }^{(5)}$ Calculated values. ${ }^{(6)}$ Values of digestible energy and crude protein (\%) estimated for Rhamdia quelen proposed by Reidel et al. (2010) and Freitas et al. (2011). 
according to the recommendations by Colégio Brasileiro de Reprodução Animal (Manual..., 2013).

Sperm survival rate was determined using eosinnigrosin staining (Murgas et al., 2003), for which $90 \mu \mathrm{L}$ of dye (3\% eosin, and $5 \%$ nigrosin) was added to $30 \mu \mathrm{L}$ of semen and subsequently smeared on glass slides. The slides were analyzed under light microscopy using a 40X objective. Stained cells through dye absorption were considered dead. Seminal $\mathrm{pH}$ was measured using a litmus paper.

For the analysis of sperm abnormality, $500 \mu \mathrm{L}$ semen were fixed in buffered formal saline $(5: 5,000$ semen:fixative) and stained with Rose bengal (Tessaro et al., 2012). Two $10 \mu \mathrm{L}$ drops of this solution were added to one end of the glass slide that was kept at an angle so the drops would slide to the other edge. Then, the slides were air-dried and analysed under lightmicroscopy using a 40X objective (Caneppele et al., 2015). From each fish, 300 spermatozoa were counted and classified as normal, or abnormal, in accordance to the guidelines by CBRA (Manual...1998).

Oocyte samples of each female were stripped in Petri dishes and weighed in an analytical scale. The samples were preserved in Alfac fixative solution for 24 hours, embedded in glycol methacrylate, and processed to monitor morphostructural alterations under light microscopy (Leonardo et al., 2004; Romagosa, 2010; Bittencourt et al., 2012) at the Histology Laboratory (Unioeste). Analysis and photodocumentation were performed using a Nikon Eclipse-50 photomicroscope (Nikon Instruments Inc., Melville, NY, USA).

The number of spawning females was calculated from the oocyte samples (percentage of females that released oocytes).

The oocytes and semen from each female were homogenized separately. Soon after fertilization and hydration (5-7 $\mathrm{min})$, the eggs of each female were transferred into $20 \mathrm{~L}$ conic fiberglass incubators. Eight hours after insemination, cleavage progress was observed under light-microscopy. The fertilization rate FR $(\%)=100$ (number of eggs at cleavage blastopore closure)/total number of oocytes $(\mathrm{N})$, for each experimental unit (Romagosa et al., 1990), was estimated using three $250 \mathrm{~mL}$ beakers, with 100 eggs from each female. Fertilized oocytes were considered to be those with translucent aspect (Okawara et al., 2015). The hatching rate was calculated as follows: HR $(\%)=100$ (number of hatched larvae)/total number of larvae (N) (Romagosa et al., 1990).
For the determination of oocyte diameter, an aliquot of extruded oocytes was fixed in Gilson solution and subsequently analysed under magnifying glass. Oocytes were measured using the software BEL View, version 7.0 (BEL Engineering s.r.l., Monza, Italy). Oocyte diameter was obtained from the arithmetic means of the horizontal and vertical axis of the oocytes.

After gamete extrusion, fish were euthanized using benzocaine solution ( $\left.250 \mathrm{mg} \mathrm{L}^{-1}\right)$, according to the resolution $n^{\circ} 876$ of Conselho Federal de Medicina Veterinária, Brazil. Subsequently, gonads (testicles and ovaries), liver, and visceral fat were removed and weighed on an analytical scale, to determine the gonadosomatic index (GSI = weight of gonads / fish total weight $\mathrm{x} 100)$, hepatosomatic index $(\mathrm{HSI}=$ weight of liver / fish total weight $\mathrm{x}$ 100), and viscerosomatic fat index (VSFI = weight of fat / fish total weight $\mathrm{x} 100)$.

Gonad samples (ovary and testicles) of six fish of each treatment were fixed in ALFAC solution, and processed using routine protocols for light-microscopy (Bittencourt et al., 2012). Tissue samples were dehydrated in a series of graded alcohol, clarified in xylene and embedded in paraffin. Subsequently, the samples were serially cut $(5 \mu \mathrm{m})$ using a microtome (Micron 340E, Thermo Scientific), mounted onto slides, and stained with haematoxylin-eosin. The slides were analysed under light-microscopy and classified by stage of gonadal maturation, according to Vazzoler (1996).

The obtained data for semen quality, fertility, somatic indexes, and oocyte diameter were subjected to the analysis of variance and, when significant, the means were subjected to the Tukey's test, at 5\% probability. The analysis was performed using the software Statistica (Statistica, Tulsa, OK, USA).

\section{Results and Discussion}

There was a significant $(\mathrm{p}<0.05)$ interaction between the factors for the GVSI (\%) in males. Males fed corn or sorghum diets supplemented with phytase, or sorghum-only diets, showed lower visceral fat deposition (Figure $1 \mathrm{~A}$ ). However, no significant $(p>0.05)$ interaction between the factors was observed in females, although coelomic fat was significantly $(p<0.05)$ reduced in females fed diets containing both ingredients and supplemented with phytase (Figure $1 \mathrm{~B}$ ).

Under adequate nutritional conditions, the relative size of tissues and organs is solely dependent on fish 
size and its life cycle. The fish internal organs tend to increase in weight proportionally to carcass growth (Shearer, 1994), while their morphological changes are related to responses to the diet, which makes their activities and/or lipid deposition more evident (Bombardelli et al., 2010).

The use of phytase in the diets can cause the resuming of the premise that animal growth is directly affected by the proportion of available $\mathrm{P}$ in the organism; however, this enzyme promotes hydrolysis of the cellular wall of the feed, degrading phytic acid and releasing other nutrients besides $\mathrm{P}$ that directly affect tissue deposition (Ferlin, 2006). Therefore, phytase supplementation is believed to have improved
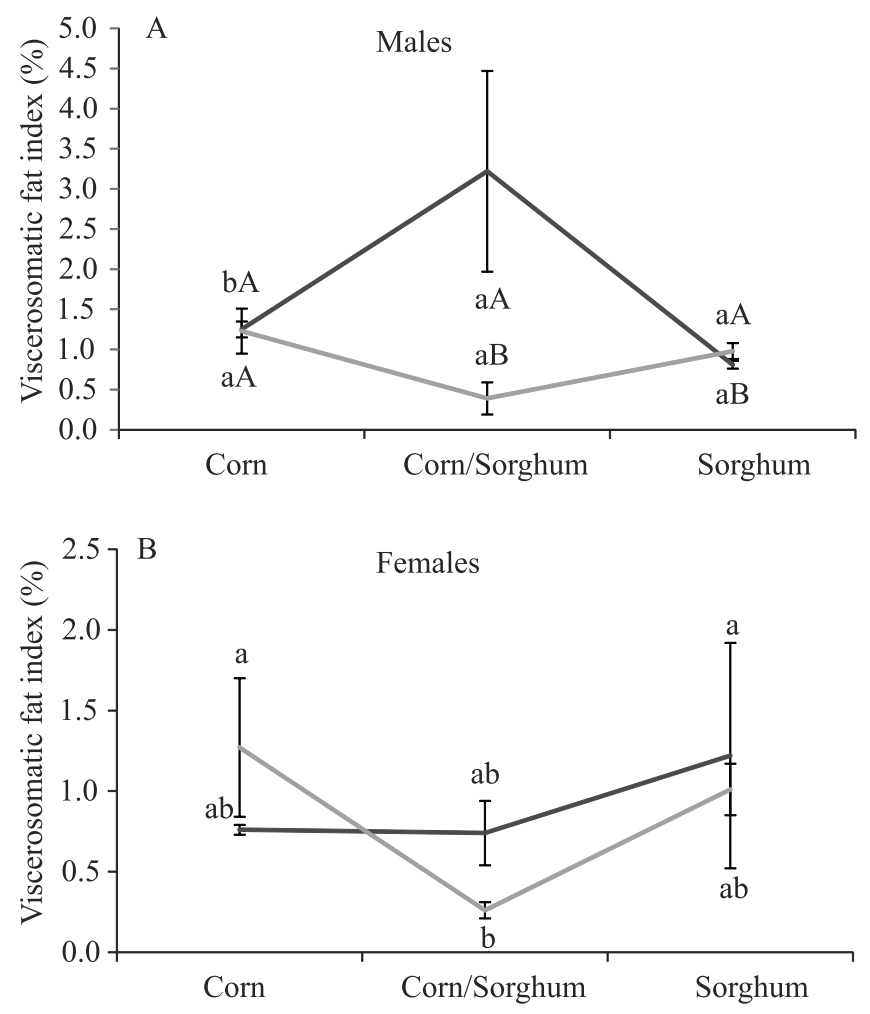

— Phytase 0 UFA —-Phytase 1500 UFA

Figure 1. Viscerosomatic fat index (\%) of Rhamdia quelen broodstock (A, males; and B, females) kept in net cages and fed phytase-supplemented diets containing corn (Zea mays) or sorghum (Sorghum bicolor) at different concentrations. Mean followed by equal uppercase letters indicate significant effect of phytase supplementation for each diet, and means with lowercase letters indicate significant difference between the ingredients, within the levels of supplementation, by Tukey's test at $5 \%$ probability. the availability of nutrients mobilized by protein synthesis, which reduced the accumulation of visceral fat in fish fed corn or sorghum diets containing phytase. The same effect was observed in fish fed sorghumonly diets, as sorghum normally contains greater concentration of $\mathrm{P}\left(0.44 \mathrm{~g} \mathrm{~kg}^{-1}\right)$ than corn $\left(0.29 \mathrm{~g} \mathrm{~kg}^{-1}\right)$ (Guimarães et al., 2005; Dicko et al., 2006).

The HSIs (\%) of $R$. quelen broodstock show a significant $(\mathrm{p}<0.05)$ interaction between feed and phytase supplementation (Figure 2). Males fed a sorghum-only diet showed lower-liver weight in the presence of phytase (Figure 2 A). However, the females showed reduced hepatic tissue in the presence of phytase, when fed diets containing corn or sorghum (Figure 2 B).
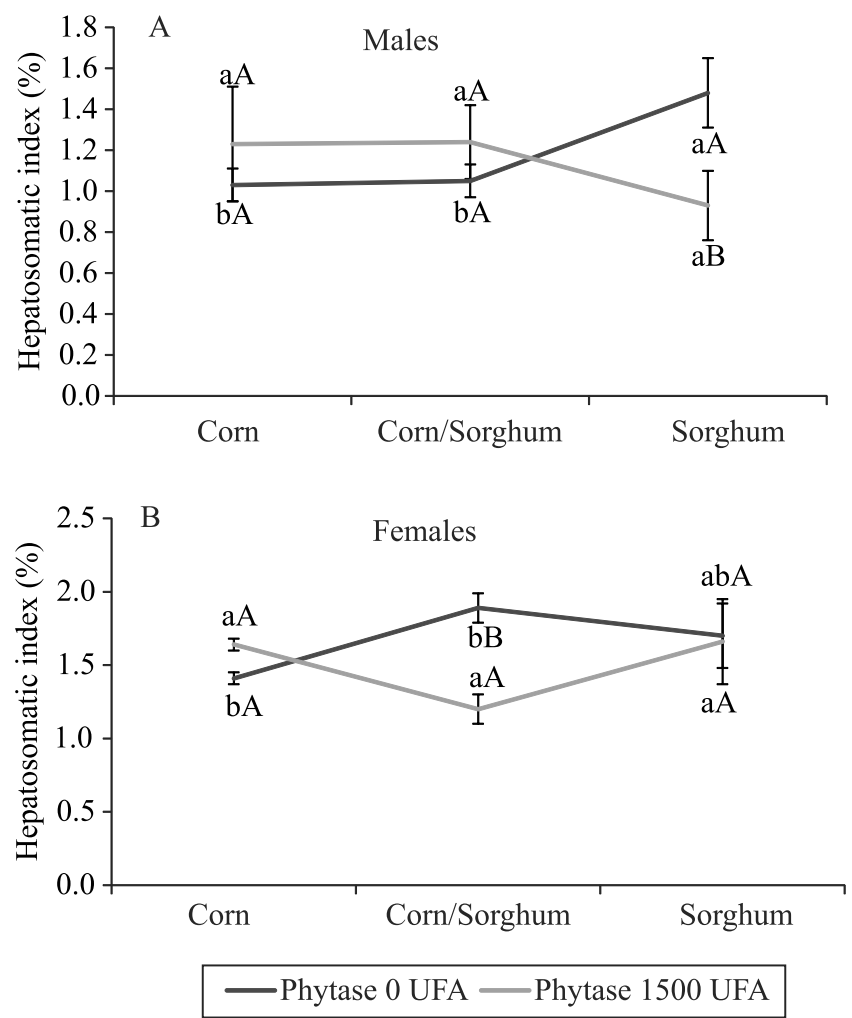

Figure 2. Hepatosomatic indexes (\%) of Rhamdia quelen broodstock kept in net pens and fed phytase-supplemented diets containing corn (Zea mays) or sorghum (Sorghum bicolor) at different concentrations. Means with equal uppercase letters indicate significant effect of phytase supplementation for each diet, and with lowercase letters indicate significant difference between the ingredients, within the levels of supplementation, by Tukey's test, at $5 \%$ probability. 
Phosphorus availability can affect the size of internal organs and, consequently, fish growth. The nutrients are metabolized in the liver and, thus, are able to alter the HIS, and the excess is converted into visceral fat (Huntingford et al., 2001; Du et al., 2006). During nutrient mobilization in the vitellogenic phase, there is a high-energy demand (lipids carbohydrates, and protein), which results in an intense synthesis mechanism by the liver (Babin et al., 2007). However, mobilization of energy reserves for vitellogenesis and reproduction (Querol et al., 2002) can lead to a reduction of the hepatic mass and visceral fat indexes during the gonadal enlargement.

According to Du et al. (2006), the HSI and VSFI depend on the quantity, balance, and quality of nutrients made available by the diet, as fish convert the excess energy of the diet into visceral fat. The results obtained in the present study for fish fed corn or sorghum diets suggest that the presence of phytase in the diets reduced the visceral fat deposition and the hepatic tissue weight (Figure 2).

The GSI of the males was significantly $(p<0.05)$ affected by phytase supplementation when they fed corn-only or sorghum-only diets. The presence of phytase increased the proportion of testicles in males fed a corn-only diet, with GSI representing 5.4\% of body weight. However, males fed a sorghum-only diet supplemented with phytase showed lower GSI, with testicles corresponding to only $2.1 \%$ of body weight (Figure $3 \mathrm{~A}$ ). The GSI of the females was not significantly affected by the evaluated diets (Figure 3 B).

Gonad maturation occurs simultaneously with vitellogenesis and, during this phase, gonadal mass increases due to vitellogenin and oocyte maturation (Hennies et al., 2003). According to Barbieri et al. (2000), the decrease in HSI due to female gonad maturation, followed by an increase in GSI, results from an increased hepatic activity due to greater demand for yolk by the developing oocytes. The presence of phytase in corn-only diets may have increased nutrient availability for the fish, affecting the results.

Ovarian histology enabled the observation of the different stages of gonadal maturation (Vazzoler, 1996), and it showed mature oocytes or oocytes at the final stages of maturation, indicating that the females were reproductively mature. Females fed sorghumonly diets, supplemented or not with phytase, had significantly (Figure 4) $(\mathrm{p}<0.05)$ larger oocytes than females from other treatment groups, but showed similar results to females fed a corn or sorghum diet (15.31:17.04) supplemented with phytase.

This could be due to the higher crude protein levels, greater quantity of starch, and greater fraction of amylose in sorghum, in comparison to corn, which results in greater nutrient availability (Rostagno, 2011), and could have led to a greater vitellogenin production (Parra et al., 2010). Furthermore, according to Adamiak et al. (2006), the increase of starch concentration in the diet is directly related to oocyte quality.

Sorghum contains higher quantity of starch (63.24\%) than corn (62.66\%) (Rostagno, 2011) and, consequently, greater distribution of protein around the endosperm
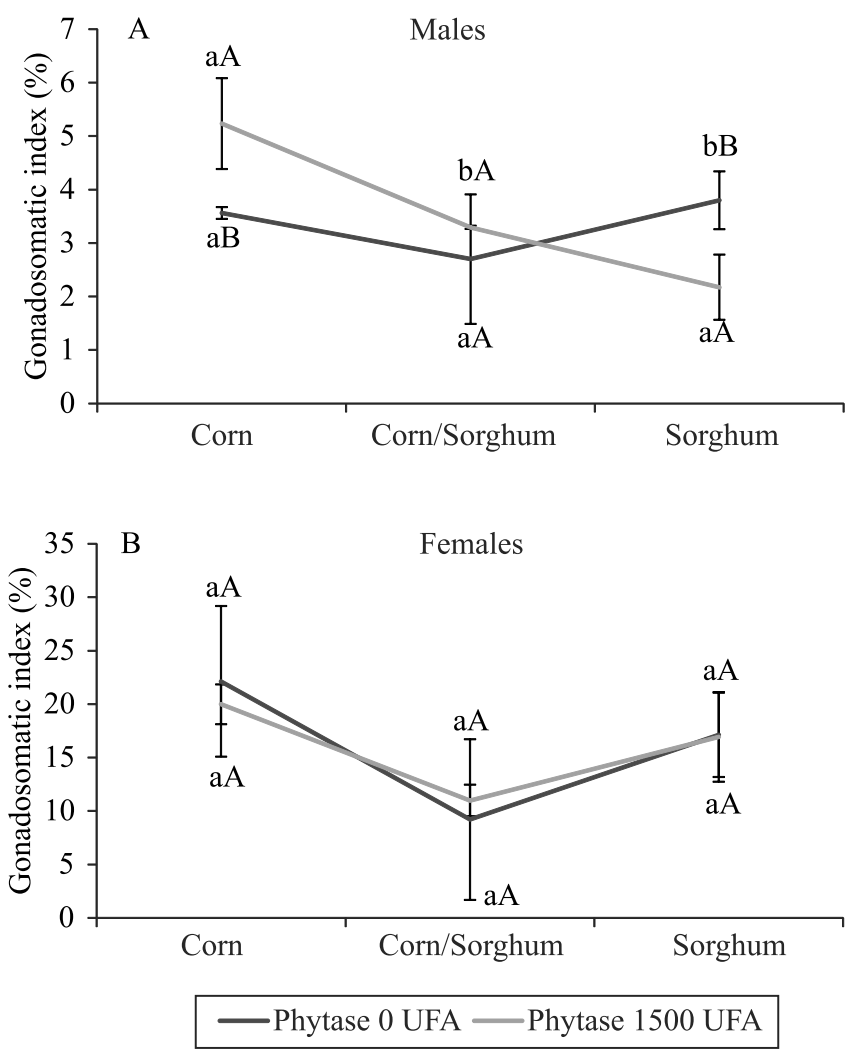

Figure 3. Gonadosomatic indexes (\%) of Rhamdia quelen broodstock kept in net cages and fed phytasesupplemented diets containing corn (Zea mays) or sorghum (Sorghum bicolor). Means with equal uppercase letters indicate significant effect of phytase supplementation for each diet, and with lowercase letters indicate significant difference between the ingredients, within the levels of supplementation, by Tukey's test, at $5 \%$ probability. 
starch, which can reduce its digestibility and that of the feed as a whole (Zardo \& Lima, 1999), affecting the physiological characteristics of the animals.

During the reproductive process, gonad maturation occurs simultaneously to vitellogenesis; when there is

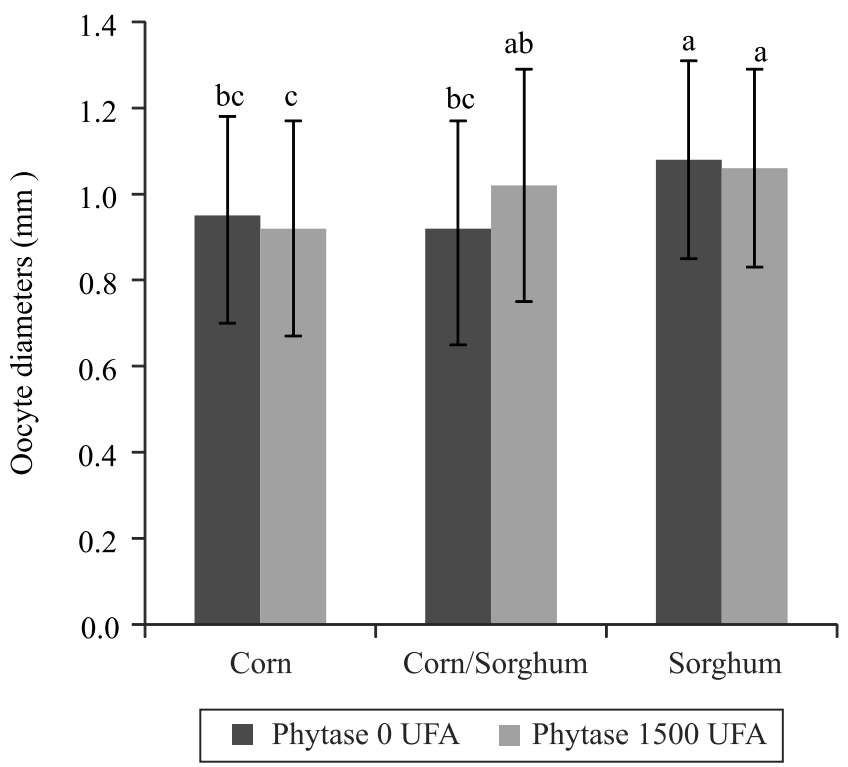

Figure 4. Oocyte diameters $(\mathrm{mm})$ of Rhamdia quelen females kept in net cages and fed phytase-supplemented diets containing corn (Zea mays) or sorghum (Sorghum bicolor) at different concentrations. Means followed by equal lowercase letters for the different diets, on the same column, do no differ by the Tukey's test, at $5 \%$ probability. an increase of GSI due to vitellogenin incorporation and oocyte maturation (Hennies et al., 2003). However, oocyte size was not affected in fish fed phytase and sorghum diets. Additionally, females with larger oocytes showed increased HSI, which suggests a greater vitellogenin production, in agreement with Moura-Costa et al. (2010), who reported that an increase of vitellogenin production and energy reserves increases liver size.

Oocyte fertilization was not significantly affected $(p>0.05)$ by phytase supplementation, and no differences were observed for this parameter between the levels of corn replacementby low-tannin sorghum in the diet (Table 2).

Histological analysis of the testicles showed characteristics of final development and maturation (Vazzoler, 1996). Testicular lobules were increased and irregular, with few spermatids in the periphery. The sperm duct was full of spermatozoa.

The different proportions of sorghum in the diet, when associated with phytase supplementation, did not significantly affect the seminal volume, sperm concentration $\left(\mathrm{SPZ} \times 10^{9} \mathrm{~mL}^{-1}\right)$, sperm abnormality, or sperm survival in $R$. quelen males (Table 3 ). There were no significant $(\mathrm{p}>0.05)$ differences in fertilization rates.

Semen parameters can be affected by several factors, such as hormonal induction, nutrition (Zhang et al., 2013), and the reproductive period (Damasceno et al., 2015). Semen is fundamental in reproduction, and its

Table 2. Fertilization rates (\%) of Rhamdia quelen females kept in net cages and fed phytase-supplemented diets containing corn (Zea mays) or sorghum (Sorghum bicolor) at different concentrations ${ }^{(1)}$.

\begin{tabular}{|c|c|c|c|c|c|c|}
\hline \multirow[t]{2}{*}{ Parameter } & \multicolumn{3}{|c|}{ Phytase, 0 FTU } & \multicolumn{3}{|c|}{ Phytase, 1,500 FTU } \\
\hline & Corn & Corn or Sorghum & Sorghum & Corn & Corn or sorghum & Sorghum \\
\hline Spawned females (\%) & 66.66 & 80.00 & 80.00 & 66.66 & 75.00 & 100.00 \\
\hline Fertilization rate $(\%)$ & $91.80 \pm 6.97$ & $86.71 \pm 4.89$ & $90.98 \pm 1.89$ & $86.40 \pm 3.40$ & $94.89 \pm 0.35$ & $95.75 \pm 2.67$ \\
\hline
\end{tabular}

Table 3. Semen parameters of Rhamdia quelen broodstock kept in net cages and fed phytase-supplemented diets containing corn (Zea mays) or sorghum (Sorghum bicolor) at different concentrations.

\begin{tabular}{|c|c|c|c|c|c|c|}
\hline \multirow[t]{2}{*}{ Parameterles } & \multicolumn{3}{|c|}{ Phytase, 0 FTU } & \multicolumn{3}{|c|}{ Phytase, 1,500 FTU } \\
\hline & Corn & Corn or sorghum & Sorghum & Corn & Corn or sorghum & Sorghum \\
\hline $\mathrm{pH}$ & $8.00 \pm 0.00$ & $8.00 \pm 0.00$ & $8.00 \pm 0.00$ & $8.00 \pm 0.00$ & $8.00 \pm 0.00$ & $8.00 \pm 0.00$ \\
\hline Sperm concentration $\left(\mathrm{SPZ} \times 10^{9} \mathrm{~mL}^{-1}\right)$ & $5.22 \pm 0.82$ & $4.39 \pm 1.02$ & $4.60 \pm 0.59$ & $4.70 \pm 1.76$ & $4.13 \pm 0.96$ & $4.19 \pm 0.36$ \\
\hline Volume (mL) & $4.25 \pm 0.65$ & $4.63 \pm 1.11$ & $3.50 \pm 0.82$ & $5.00 \pm 0.41$ & $3.37 \pm 0.95$ & $5.63 \pm 2.49$ \\
\hline Sperm normality (\%) & $93.75 \pm 3.20$ & $95.75 \pm 0.75$ & $95.92 \pm 1.53$ & $95.17 \pm 1.70$ & $93.83 \pm 0.63$ & $97.17 \pm 0.95$ \\
\hline Sperm survival (\%) & $89.67 \pm 0.58$ & $89.72 \pm 0.48$ & $89.37 \pm 0.61$ & $89.06 \pm 0.91$ & $90.0 \pm 0.00$ & $90.0 \pm 0.00$ \\
\hline
\end{tabular}


high quality, associated with excellent oocytes, often results in high-fertilization rates and good survival rates of offspring.

\section{Conclusion}

Complete (100\%) corn (Zea mays) replacement by low-tannin sorghum (Sorghum bicolor) can be performed without compromising the somatic indexes or the reproductive parameters of Rhamdia quelen males and females.

\section{Acknowledgments}

To Conselho Nacional de Desenvolvimento Científico e Tecnológico (CNPq, process No. 552 223/2011-5) and to Fundação Araucária, for financial support.

\section{References}

ADAMIAK, S.J.; POWELL, K.; ROOKE, J.A.; WEBB, R.; SINCLAIR, K.D. Body composition, dietary carbohydrates and fatty acids determine post-fertilisation development of bovine oocytes in vitro. Reproduction, v.131, p.247-258, 2006. DOI: 10.1530/rep.1.00871.

ALVAREZ-LAJONCHÈRE, L. Nutrición de reproductores de peces marinos. In: SIMPOSIUM INTERNACIONAL DE NUTRICIÓN ACUÍCOLA, 8., 2006, León. Anales. León: Universidad Autónoma de Nuevo León, 2006. p.1-19.

ANGEL, R.; TAMIM, N.M.; APPLEGATE, T.J.; DHANDU, A.S.; ELLESTAD, L.E. Phytic acid chemistry: influence on phytinphosphorus availability and phytase efficacy. The Journal of Applied Poultry Research, v.11, p.471-480, 2002. DOI: 10.1093/ japr/11.4.471.

BABIN, P.J.; CERDÀ, J.; LUBZENS, E. (Ed.). The fish oocyte: from basic studies to biotechnological applications. Dordrecht: Springer, 2007. 76p. DOI: 10.1007/978-1-4020-6235-3.

BARBIERI, G.; VERMULM JR., H.; GIAMAS, M.T.D.; TEIXEIRA-FILHO, A.R.; CAMPOS, E.C. Biologia populacional da tilápia, Oreochromis niloticus, da represa de Guarapiranga, São Paulo: I. Estrutura da população, idade e crescimento. Boletim do Instituto de Pesca, v.26, p.1-7, 2000.

BITTENCOURT, F.; SOUZA, B.E. de; LUI, T.A.; BORELLA, M.I.; BOSCOLO, W.R.; FEIDEN, A.; ROMAGOSA, E. Protein diets promote the maturation of oocytes and spawning of Piaractus mesopotamicus kept in cages. Journal of Applied Ichthyology, v.28, p.886-893, 2012. DOI: 10.1111/jai.12060.

BOMBARDELLI, R.A.; HAYASHI, C.; NATALI, M.R.M.; SANCHES, E.A.; PIANA, P.A. Níveis de energia digestível sobre os desempenhos reprodutivo e zootécnico e a deposição de lipídios nos hepatócitos de machos de tilápia-do-nilo. Revista Brasileira de Zootecnia, v.39, p.941-949, 2010. DOI: 10.1590/ S1516-35982010000500001.
BOMBARDELLI, R.A.; MÖRSCHBÄCHER, E.F.; CAMPAGNOLO, R.; SANCHES, E.A.; SYPERRECK, M.A. Dose inseminante para fertilização artificial de ovócitos de jundiá cinza, Rhamdia quelen (Quoy \& Gaimardm, 1824). Revista Brasileira de Zootecnia, v.35, p.1251-1257, 2006. DOI: 10.1590/ S1516-35982006000500001.

CANEPPELE, D.; SANCHES, E.A.; ROMAGOSA, E. Sperm production of Steidachneridion parahybae (Steindachner 1877) and the effect of hormonal induction throughout one reproductive cycle. Journal of Applied Ichthyology, v.31, p.54-61, 2015. DOI: 10.1111/jai.12732.

CARNEIRO, P.C.F.; BENDHACK, F.; MIKOS, J.D. Processamento: o jundiá como matéria prima. Panorama da Aqüicultura, v.13, p.17-21, 2003.

CARVALHO, L.S.S.; FAGUNDES, N.S.; LITZ, F.H.; SAAR, A.G.L.; FERNANDES, E. de A. Sorgo grão inteiro ou moído em substituição ao milho em rações de frangos de corte. Enciclopédia Biosfera, v.11, p.17-57, 2015.

COLDEBELLA, I.J.; RADÜNZ NETO, J.; MALLMANN, C.A.; VEIVERBERG, C.A.; BERGAMIN, G.T.; PEDRON, F.A.; FERREIRA, D.; BARCELLOS, L.J.G. The effects of different protein levels in the diet on reproductive indexes of Rhamdia quelen females. Aquaculture, v.312, p.137-144, 2011. DOI: 10.1016/j.aquaculture.2010.12.021.

DAMASCENO, D.Z.; KRAUSE, R.A.; ADAMES, M.S.; NEUMANN, G.; GIBATHE, A.; BOMBARDELLI, R.A.; ROMAGOSA, E. Induced spermiation of Pimelodus britskii (Teleostei: Pimelodidae) during the reproductive period. Aquaculture Research, v.48, p.862-874, 2015. DOI: 10.1111/ are.12930.

DICKO, M.H.; GRUPPEN, H.; TRAORÉ, A.S.; VORAGEN, A.G.J.; BERKEL, W.J.H. van. Sorghum grain as human food in Africa: relevance of content of starch and amylase activities. African Journal of Biotechnology, v.5, p.384-395, 2006.

DIEMER, O.; BITTENCOURT, F.; BARCELLOS, L.G.; BOSCOLO, W.R.; FEIDEN, A.; ROMAGOSA, E. Lysine in the diet of Rhamdia voulezi male broodstocks confined in net cages. Aquaculture, v.434, p.93-99, 2014. DOI: 10.1016/j. aquaculture.2014.07.029.

DU, Z.-Y.; LIU, Y.-J.; TIAN, L.X.; HE, J.-G.; CAO, J.-M.; LIANG, G.-Y. The influence of feeding rate on growth, feed efficiency and body composition of juvenile grass carp (Ctenopharyngodon idella). Aquaculture Internacional, v.14, p.247-257, 2006. DOI: 10.1007/s10499-005-9029-7.

DUARTE, J. de O. Cultivo do sorgo: mercado e comercialização: a produção de sorgo granífero no Brasil. 6.ed. Sete Lagoas: Embrapa Milho e Sorgo, 2010. Available at: <http://www.cnpms. embrapa.br/publicacoes/sorgo_6_ed/mercado.htm $>$. Accessed on: Nov. 292015.

FARREL, D.J.; MARTIN, E.; DU PREEZ, J.J.; BONGARTS, M.; BETTS, M.; SUDAMAN, A.; THOMSON, E. The beneficial effects of a microbial feed phytase in diets of broiler chickens and ducklings. Journal of Physiology and Animal Nutrition, v.69, p.278-283, 1993. DOI: 10.1111/j.1439-0396.1993.tb00815.x. 
FERLIN, M. Efeito da fitase sobre a utilização da energia metabolizável da dieta em frangos de corte. 2006. 98p. Dissertação (Mestrado) - Universidade Federal de Pelotas, Pelotas.

FRACALOSSI, D.M.; MEYER, G.; SANTAMARIA, F.M.; WEINGARTNER, M.; ZANIBONI FILHO, E. Desempenho do jundiá, Rhamdia quelen, e do dourado, Salminus brasiliensis, em viveiros de terra na região Sul do Brasil. Acta Scientiarum. Animal Sciences, v.26, p.345-352, 2004. DOI: 10.4025/ actascianimsci.v26i3.1806.

FREITAS, J.M.A. de; SARY, C.; LUCHESI, J.D.; FEIDEN, A.; BOSCOLO, W.R. Proteína e energia na dieta de jundiás criados em tanques-rede. Revista Brasileira de Zootecnia, v.40, p.26282633, 2011. DOI: 10.1590/S1516-35982011001200002.

GUIMARÃES, P.E. de O.; ROBEIRO, P.E. de A.; PAES, M.C.D.; SCHAFFERT, R.E.; ALVES, V.M.C.; COELHO, A.M.; NUTTI, M.; VIANA, J.L.C.; NOGUEIRA, A.R. de A.; SOUZA, G.B. de. Caracterização de linhagens de milho quanto aos teores de minerais nos grãos. Sete Lagoas: Embrapa Milho e Sorgo, 2005. 4p. (Embrapa Milho e Sorgo. Circular técnica, 64).

HENNIES, M.; WIESMANN, M.; ALLNER, B.; SAUERWEIN, H. Vitellogenin in carp (Cyprinus carpio) and perch (Perca fluviatilis): purification, characterization and development of an ELISA for the detection of estrogenic effects. Science of the Total Environment, v.309, p.93-103, 2003. DOI: 10.1016/S00489697(03)00005-6.

HUNTINGFORD, F.A.; CHELLAPPA, S.; TAYLOR, A.C.; STRANG, R.H.C. Energy reserves and reproductive investment in male three spined sticklebacks, Gasterosteus aculeatus. Ecology of Freshwater Fish, v.10, p.111-117, 2001. DOI: 10.1034/j.16000633.2001.100206.x.

IZQUIERDO, M.S.; FERNÁNDEZ-PALACIOS, H.; TACON, A.G.J. Effect of broodstock nutrition on reproductive performance of fish. Aquaculture, v.197, p.25-42, 2001. DOI: 10.1016/S00448486(01)00581-6.

LEONARDO, A.F.G.; ROMAGOSA, E.; BORELLA M.I.; BATLOUNI, S.R. Inducedspawning of hatchery-raised Brazilian catfish, cachara Pseudoplatystoma fasciatum (Linnaeus, 1766). Aquaculture, v.240, p.451-461, 2004. DOI: 10.1016/j. aquaculture.2003.11.030.

MAENZ, D.D. Enzimatic characteristics of phytases as they relate to their use in animal feeds. In: BEDFORD, M.R.; PARTRIDGE, G.G. (Ed.). Enzymes in farm animal nutrition. Wallingford: Cab Publishing, 2001. p.61-84. DOI: 10.1079/9780851993935.0061.

MANUAL para exame andrológico e avaliação de sêmen animal. 2.ed. Belo Horizonte: Colégio Brasileiro de Reprodução Animal, 1998. 49p.

MANUAL para exame andrológico e avaliação de sêmen animal. 3.ed. Belo Horizonte: Colégio Brasileiro de Reprodução Animal, 2013. 104p.

MARDINI, C.V.; SILVEIRA, M.A.; BARENHO, D.H.L. Técnica de indução da desova em jundiá (Rhamdia quelen) empregada na estação experimental de piscicultura da Lagoa dos Quadros. Porto Alegre: Secretaria da Agricultura, 1981. 14p. (Documento ocasional, 4).
MAY, A.; ALBUQUERQUE FILHO, M.R. de; RODRIGUES, J.A.S.; LANDAU, E.C.; PARRELLA, R.A. da C.; MASSAFERA, $R$. Cultivares de sorgo para o mercado brasileiro da safra 2011/2012. Sete Lagoas: Embrapa Milho e Sorgo, 2011. 28p. (Embrapa Milho e Sorgo. Documentos, 117).

MOURA-COSTA, D.D.; FILIPAK NETO, F.; COSTA, M.D.M.; MORAIS, R.N.; GARCIA, J.R.E.; ESQUIVEL, B.M.; RIBEIRO, C.A.O. Vitellogenesis and other physiological responses induced by 17- $\beta$-estradiol in males of freshwater fish Rhamdia quelen. Comparative Biochemistry and Physiology, Part C, v.151, p.248-257, 2010. DOI: 10.1016/j.cbpc.2009.11.002.

MURGAS, L.D.S.; FRANCISCATTO, R.T.; SANTOS, A.G.O. Avaliação espermática pós-descongelamento em Piracanjuba (Brycon orbignyanus, Vallenciennes, 1849). Revista Brasileira de Zootecnia, v.32, p.1810-1814, 2003. DOI: 10.1590/S151635982003000800002 .

NAVARRO, R.D.; MATTA, S.L.P.; LANNA, E.A.T.; DONZELE J.L.; RODRIGUES S.S.; SILVA, R.F.; CALADO, L.L.; RIBEIROFILHO, O.P. Níveis de energia digestível na dieta de piauçu (Leporinus macrocephalus) no desenvolvimento testicular em estágio pós-larval. Zootecnia Tropical, v.24, p.153-163, 2006.

OKAWARA, R.Y.; SANCHES, E.A.; CANEPPELE, D.; DAMASCENO, D.Z.; ROMAGOSA, E. Ovulation and initial rearing of Steindachneridion parahybae (Siluriformes: Pimelodidae) larvae from different accumulated thermal units. Ichthyological Research, v.62, p.495-503, 2015. DOI: 10.1007/ S10228-015-0465-8.

PARRA, J.E.G.; RADÜNZ-NETO, J.; VEIVERBERG, C.A.; LAZZARI, R.; BERGAMIN, G.T.; CORRÊIA, V.; FERREIRA, C.C.; FERREIRA, F.W. Desempenho reprodutivo de fêmeas de jundiá alimentadas com diferentes fontes protéicas. Archivos de Zootecnia, v.226, p.255-265, 2010.

PEZZATO, L.E.; MIRANDA, E.C. de; BARROS, M.M.; PINTO, L.G.Q.; FURUYA, W.M.; PEZZATO, A.C. Digestibilidade aparente de ingredientes pela tilápia do Nilo (Oreochromis niloticus). Revista Brasileira de Zootecnia, v.31, p.1595-1604, 2002. DOI: 10.1590/S1516-35982002000700001.

QUEROL, M.V.; QUEROL, E.; GOMES, N.N.A. Fator de condição gonadal, índice hepatossomático e recrutamento como indicadores do período de reprodução de Loricariichthys platymetopon (Osteichthyes, Loricariidae), bacia do rio Uruguai médio, sul do Brasil. Iheringia. Série Zoologia, v.92, p.1-112, 2002. DOI: $10.1590 / \mathrm{S} 0073-47212002000300008$.

REIDEL, A.; BOSCOLO, W.R.; FEIDEN, A.; ROMAGOSA, E. The effect of diets with different levels of protein and energy on the process of final maturation of the gametes of Rhamdia quelen stocked in cages. Aquaculture, v.298, p.354-359, 2010. DOI: 10.1016/j.aquaculture.2009.11.005.

ROCHA, B.C.; POUEY, J.L.O.F.; ENKE, D.B.S.; XAVIER, E.G; ALMEIDA, D.B. Suplementação de fitase microbiana na dieta de alevinos de jundiá: efeito sobre o desempenho produtivo e as características de carcaça. Ciência Rural, v.37, p.1772-1778, 2007. DOI: $10.1590 /$ S0103-84782007000600042.

ROMAGOSA, E. Reproductive status in females of the Brazilian catfish, Pseudoplatystoma fasciatum reared in cages. Journal 
of Ichthyology, v.2, p.806-811, 2010. DOI: 10.1111/j.14390426.2010.01532.x

ROMAGOSA, E.; DE PAIVA, P.; GODINHO, H.M. Pattern of oocytes diameter frequency distribution in females of the pacu, Piaractus mesopotamicus (Holmberg 1887) (= Colossoma mitrei Berg, 1895) induced to spawn. Aquaculture, v.86, p.105-110, 1990. DOI: 10.1016/0044-8486(90)90225-C.

ROSTAGNO, H.S. (Ed.). Tabelas brasileiras para aves e suínos: composição de alimentos e exigências nutricionais. Viçosa: Ed. da UFV, 2011. 252p.

SANCHES, E.A.; NEUMANN, G.; TOLEDO, C.P.R. de; BOMBARDELLI, R.A.; PIANA, P.A.; ROMAGOSA, E. Temperature and storage period over spermatic parameters of jundiá, Rhamdia quelen (Quoy \& Gaimard, 1824). Aquaculture Research, v.44, p.534-541, 2013. DOI: 10.1111/j.13652109.2011.03056.x.

SHEARER, K.D. Factors affecting the proximate composition of cultured fishes with emphasis on salmonids. Aquaculture, v.119, p.63-88, 1994. DOI: 10.1016/0044-8486(94)90444-8.

SILVA, J.D.T.; DIAS, L.T.S.; MACHADO, C.R.; CARVALHO, M.R.B.; RIZZO, P.V. Uso de sorgo com baixo teor em taninos na alimentação de frangos de corte. Nucleus Animalium, v.1, p.3952, 2009. DOI: $10.3738 / 1982.2278 .281$.
TESSARO, L.; TOLEDO, C.P.R.; NEUMANN, G.; KRAUSE, R.A.; MEURER, F.; NATALI, M.R.M.; BOMBARDELLI, R.A. Growth and reproductive characteristics of Rhamdia quelen males fed on different digestible energy levels in the reproductive phase. Aquaculture, v.326-329, p.74-80, 2012. DOI: 10.1016/j. aquaculture.2011.11.012.

VALLE, F.L. de P. Uso de fitase em dietas comerciais para frangos de corte contendo ou não ingredientes de origem animal. 2010. 93p. Dissertação (Mestrado) - Universidade Federal do Paraná, Curitiba.

VAZZOLER, A.E.A. de M. Biologia da reprodução de peixes teleósteos: teoria e prática. São Paulo: Sociedade Brasileira de Imunologia; Maringá: Ed. Eduem, 1996. 169p.

WIRTZ, S.; STEINMANN, P. Sperm characteristics in perch Perca fluviatilis L. Journal of Fish Biology, v.68, p.1896-1902, 2006. DOI: $10.1111 /$ j.1095-8649.2006.01065.x.

ZARDO, A.O.; LIMA, G.J.M.M. de. Alimentos para suínos. Bipers, ano 8, 1999. 71p. (Embrapa-CNPSA. Boletim informativo, 12; Emater/RS. Pesquisa \& extensão).

ZHANG, M.-Z.; LI, G.-L.; ZHU, C.-H.; DENG, S.-P. Effects of fish oil on ovarian development in spotted scat (Scatophagus argus). Animal Science Reproduction, v.141, p.90-97, 2013. DOI: 10.1016/j.anireprosci.2013.06.020.

Received on July 10, 2016 and accepted on December $1^{\circ}, 2016$ 